\title{
Hubungan Antara Self Efficacy Dan Social Support Dengan Tingkat Stres Pada Mahasiswa Akhir Penyusun Skripsi Di FIP UNNES
}

Tahun 2019

\author{
Kiki Anggun Saputri \\ Universitas Negeri Semarang, Semarang Indonesia \\ kikianggunsaputri96@gmail.com \\ DYP. Sugiharto \\ Universitas Negeri Semarang, Semarang Indonesia \\ s dyp@yahoo.com
}

\begin{abstract}
Abstrak
Penelitian ini memiliki tujuan untuk mengetahui hubungan antara self efficacy dan social support dengan tingkat stress pada mahasiswa akhir penyusun skripsi di FIP UNNES tahun 2019. Permasalahan yang mendasari dari penelitian ini adalah terjadinya beberapa fenomena di FIP UNNES. Fenomena-fenomena tersebut berhubungan dengan tingkat stres menyusun skripsi. Banyak mahasiswa yang mengalami streskarena kesulitan dalam menentukan judul skripsi, dosen pembimbing sibuk, kesulitan menemukan sumber-sumber yang relevan dan kurangnya dukungan dari orang lain. Metode yang digunakan dalam penelitian ini adalah metode kuantitatif dengan menggunakan dua alat pengumpul data yaitu skala pikologis dan teknik wawancara. Hasil dari penelitian ini adalah terdapat hubungan yang signifikan antara self efficacy dan social support dengan tingkat stress. Hasil penelitian ini juga bermanfaat bagi Jurusan dan Fakultas dalam menyusun kebijakankebijakan akademik serta pendukung lainnya yang dapat menekan laju tingkat stresserta meningkatkan self efficacy dan social support mahasiswa
\end{abstract}

Kata kunci: tingkat stres; self efficacy; social support 


\begin{abstract}
The Relationship Between Self Efficacy and Social Support With the Level of Stress in Final Thesis Compilers in FIP UNNES. The Study aims to determine the relationship between self efficacy and social support with stress levels in the final student of the thesis at the FIP unnes in 2019. The underlying problem of this research is the occurrence of several phenomena in FIP UNNES. These phenomena relate to the level of stress composing thesis. Many students are stressedbecause of difficulties in determining the title of the thesis, the lecturer is busy, the difficulty of finding relevant sources and the lack of support fromothers. The methods used in this study is a quantitative methods that uses two data collection tools namely the picological scale and interview techniques. The result of this study are that there is a significant relationship between self efficacy and social support with stress levels. The results of this study are also beneficial for the department and the faculty in drafting academic policies as well as other advocates that can suppress the rate of stress and improve self efficacy and social support students
\end{abstract}

Keywords: stress level; self efficacy; social support

\title{
A. Pendahuluan
}

Stres adalah suatu kondisi tertekan karena adanya ketidaksesuaian antara tuntutan yang diterima oleh individu dengan kemampuan untuk mengatasinya. Maramis (2009) menyatakan bahwa, stres yaitu segala permasalahan atau tuntutan penyesuaian diri yang dapat menganggu keseimbangan individu, apabila individu tidak mampu mengatasinya dengan baik maka akan muncul gangguan pada badan maupun jiwa. Stres dapat terjadi oleh siapapun tidak terkecuali seorang mahasiswa. Stres yang dialami mahasiswa banyak diakibatkan oleh masalah akademik. Weidner, Kohlman, Dotzauer, dan Burns (1996) menyatakan bahwa stres akademik adalah stres yang berhubungan dengan kegiatan pendidikan yang terjadi dalam masa pendidikan yang disebabkan oleh tuntutan yang timbul saat mahasiswa dalam masa pendidikan. Pada bidang akademik, idealnya seorang mahasiswa penyusun skripsi dapat berperan aktif, memiliki intelegensi yang tinggi, berwawasan luas, disiplin, dan rajin dalam 
mengikuti bimbingan skripsi sampai diselesaikannya tugas-tugas yang diberikan oleh dosen pembimbing, sehingga potensi akademik yang dimiliki oleh seorang mahasiswa dapat tercapai dengan baik hingga dapat lulus kuliah tepat waktu. Semakin rendah mahasiswa mengalami stres, maka akan semakin tinggi kesempatan mahasiswa dalam meraih prestasi akademik. Tamara dan Chris (2018) dalam penelitiannya menyampaikan bahwa tingkat stres yang tinggi memiliki pengaruh terhadap penurunan prestasi akademik. Dampak stres bagi mahasiswa penyusun skripsi tentu sangat jelas. Menurut Agung \& Santi (2013) skripsi jika dibiarkan berlarut-larut menyebabkan mahasiswa tidak dapat segera menyelesaikan skripsi dan tidak dapat segera lulus dari bangku perkuliahan. Pada umumnya dalam mencapai gelar sarjana S1 (Strata-1) mahasiswa membutuhkan 8 semester untuk selesai dan lulus dari bangku perkuliahan. Namun setiap tahun selalu ditemukan mahasiswa yang mencapai semester akhir atau batas 14 semester dari Universitas. Hal tersebut tentu tidak baik untuk mahasiswa akhir yang sedang menyusun skripsi maupun untuk Universitas. Dalam hal ini banyak mahasiswa yang sengaja untuk mengundurkan diri disemester akhir perkuliahan atau terpaksa di drop out dari Universitas.

Berdasarkan data yang dihimpun dari Fakultas Ilmu Pendidikan UNNES per bulan Juni 2019, didapatkan data bahwa mahasiswa akhir semester 14 atau angkatan 2012 di FIP UNNES dari total 1193 mahasiswa, masih terdapat 77 mahasiswa aktif yang sedang menyelesaikan skripsi. Berdasarkan hasil wawancara dengan beberapa mahasiswa bahwa stres yang dialami mahasiswa dikarenakan kesulitan dalam menentukan judul skripsi, dosen pembimbing yang sangat sibuk, kesulitan menemukan sumber-sumber yang relevan, tidak menemukan jurnal-jurnal yang cocok dengan judul penelitian, tidak mendapatkan dukungan dari orang lain dan kurang bisa memanfaatkan waktu dengan baik. Shofiyanti (2014) menyatakan bahwa saat ini mahasiswa mengalami masalah 
akademik yangcukup beragam. Secara fisik, tiap responden mengalami semua reaksi stres yang umum terjadi saat proses penyusunan proposal hingga skripsi, seperti berkeringat, mudah lelah, gugup, gelisah, takut, khawatir, sangat sensitif atau peka, dan sebagainya. Secara psikis, tiap responden mengalami berbagai perubahan emosi dan perilaku terhadap tekanan maupun konflik yang terjadi selama proses penyusunan proposal hingga skripsi.Salah satu faktor yang mempengaruhi munculnya stres pada mahasiswa akhir penyusun skripsi adalah faktor internal berupa faktor kognitif yaitu memiliki keyakinan apakah mereka memiliki kemampuan untuk menghadapi suatu kejadian dengan efektif. Bandura (1997) menyatakan bahwa self efficacy mempengaruhi stres dan kecemasan melalui perilaku yang dapat mengatasi masalah (coping behavior). Bandura (dalam Feist \& Feist, 2010) mendefinisikan self efficacy sebagai keyakinan seseorang dalam kemampuannya untuk melakukan suatu bentuk kontrol terhadap keberfungsian orang itu sendiri dan kejadian dalam lingkungan. Semakin tinggi self efficacy seseorang maka semakin gigih pula usaha yang dilakukan, banyak penelitian membuktikan bahwa self efficacy dapat meningkatkan kualitas dan psikososial seseorang (Bandura, 1997). Semakin kuat self efficacy individu semakin kuat dan tahan lama pula usaha yang akan dilaksanakannya. Ketika menemui kesulitan, seseorang yang meragukan kekuatannya akan mengurangi usaha dan menyerah, sementara seseorang yang memiliki self efficacy yang kuat akan memunculkan usaha yang lebih besar untuk menguasai tantangan atau masalah.

Selain itu stres yang dialami oleh mahasiswa berpengaruh pada pola perilaku sehari-hari. Mahasiswa menjadi malas mengerjakan skripsi, tidak memiliki minat menyelesaikan revisi skripsi karena stres yang semakin jadi. Hal ini berdampak pada selesainya pengerjaan skripsi yang semakin lama hingga batas maksimal 14 semester. Hal ini sesuai dengan hasil penelitian dari Zakaria (2017) menyatakan bahwa faktor yang menyebabkan mahasiswa mengalami stres dalam menyusun skripsi karena kesulitan menuang pikiran dalam bentuk tulisan, 
tekanan dari orang tua agar cepat lulus dan malas dalam mengerjakan skripsi.Faktor eksternal yang mempengaruhi tingkat stres adalah hubungan mahasiswa dengan lingkungan sosialnya. Kondisi lingkungan yang mempengaruhi mahasiswa mengalami stres berupa lingkungan yang rendah pengawasan. Mahasiswa melakukan interaksi di lingkungan melibatkan orang-orang di sekitarnya seperti orang tua, dosen pembimbing, kekasih dan teman sebayanya. Akibat dari lingkungan yang rendah pengawasan mahasiswa tidak mendapatkan kontrol dari pihak lain dalam melakukan aktivitas, sehingga mahasiswa bebas melakukan aktivitas tanpa memperhatikan adanya tanggung jawab terhadap tugas akademiknya. Mahasiswa membutuhkan social support yang positif untuk mendukung mahasiswa dalam berinteraksi sosial dan belajar untuk bertanggung jawab. Menurut Sarafino dan Smith (2011: 81), dukungan sosial adalah suatu kesenangan, perhatian, penghargaan, ataupun bantuan yang dirasakan dari orang lain atau kelompok.Menurut Turner (dalam Sarafino 1994:103), social support dapat menghilangkan atau mengurangi stres dari berbagai macam masalah. Sarafino (1994:102) menyatakan bahwa social support mengacu pada memberikan kenyamanan pada orang lain, merawatnya atau menghargainya. Social support dapat membuat seseorang merasa nyaman, didukung, dicintai pada saat individu tersebut dalam kondisi stress, terbangunya perasaan harga diri, kompeten dan bernilai. Sehingga dapat membuat individu merasa mampu untuk menghadapi kendala atau kesulitan dalam melaksanakan sesuatu. Dengan dukungan yang diterima, mahasiswa yang sedang menyusun skripsi dapat bersemangat dan yakin akan kemampuannya, serta mengupayakan berbagai usaha untuk mencapai target atau goal.

Dari pembahasan diatas, peneliti ingin melakukan penelitian di Fakultas Ilmu Pendidikan Universitas Negeri Semarang untuk mencari jawaban dari rumusan masalah bagaimana hubungan antara self efficacy dan social support 
dengan tingkat stress pada mahasiswa akhir penyusun skripsi di FIP UNNES tahun 2019 sehinggga tujuan penelitian ini untuk mengetahui hubungan antara self efficacy dan social support dengan tingkat stress pada mahasiswa akhir penyusun skripsi di FIP UNNES tahun 2019. Metode yang digunakan dalam penelitian ini yaitu menggunakan jenis penelitian kuantitatif kolerasional karena peneliti ingin mengetahui tentang hubungan antar variabel yang diteliti. Penelitian ini juga bermanfaat bagi Jurusan dan Fakultas dalam menyusun kebijakan-kebijakan akademik serta pendukung lainnya yang dapat menekan laju tingkat stres mahasiswa akhir penyusun skripsi serta meningkatkan self efficacy dan social support mahasiswa.

\section{B. Pembahasan}

Dalam pembasahan ini akan diuraikan penjelaskan mengenai pokok bahasan dari penelitian ini yaitu tingkat stres, self efficacydan social support. Metode penelitian juga akan dijelaskan pada bab ini. Berikut uraian dari pokok pembahasan dalam penelitian ini:

\section{Tingkat Stres}

\section{a. Pengertian Tingkat Stres}

Menurut Sarafino sebagaimana dikutip oleh Smet (1994: 110) mendefinisikan stres sebagai suatu kondisi yang disebabkan oleh transaksi antara individu dengan lingkungan yang menimbulkan jarak antara tuntutan-tuntutan yang berasal dari berbagai situasi dengan sumber-sumber daya sistem biologis, psikologis dan sosial seseorang. Lazarus sebagaimana dikutip oleh Hasan (2008:77) memberikan definisi stres yang mencakup berbagai faktor yang terdiri dari stimulus, tanggapan, penilaian kognitif terhadap ancaman, gaya pertahanan, perlindungan psikologis dan situasi social.

Berdasarkan pendapat di atas dapat disimpulkan bahwa stres merupakan tekanan, tuntutan maupun kondisi yang disebabkan oleh transaksi antara individu dengan lingkungan yang menimbulkan jarak antara tuntutan-tuntutan yang 
berasal dari berbagai situasi dengan sumber-sumber daya sistem biologis, psikologis dan sosial seseorang.

\section{b. Aspek-aspek Stres}

Mahasiswa yang sedang mengalami stres dapat dilihat dari beberapa aspek. Aspek-aspek stres menurut Sarafino \& Smith (2012: 33) yaitu :

1) Aspek biologis

Aspek biologis dari stress berupa gejala fisik. Gejala fisik dari stres yang dialami individu antara lain sakit kepala, gangguan tidur, gangguan pencernaan, gangguan makan, gangguan kulit, dan produksi keringat yang berlebihan. Disamping itu gejala fisik lainnya juga ditandai dengan adanya otot-otot tegang, pernafasan dan jantung tidak teratur, gugup, cemas, gelisah, perubahan nafsu makan, maag, dan lain sebagainya.

2) Aspek psikologis

Aspek psikologis stress yaitu berupa gejala psikis. Gejala psikis dari stres antara lain:

a) Gejala kognisi (pikiran) kondisi stres dapat mengganggu proses pikir individu. Individu yang mengalami stres cenderung mengalami gangguan daya ingat, perhatian, dan konsentrasi. Disamping itu gejala kognisi ditandai juga dengan adanya harga diri yang rendah, takut gagal, mudah bertindak memalukan, cemas akan masa depan dan emosi labil.

b) Gejala emosi, kondisi stres dapat mengganggu kestabilan emosi individu. Individu yang mengalami stres akan menunjukkan gejala mudah marah, kecemasan yang berlebihan terhadap segala sesuatu, merasa sedih, dan depresi.

c) Gejala tingkah laku, kondisi stres dapat mempengaruhi tingkah laku sehari-hari yang cenderung negatif sehingga menimbulkan masalah dalam hubungan interpersonal. Gejala tingkah laku yang muncul adalah sulit 
bekerja sama, kehilangan minat, tidak mampu rileks, mudah terkejut atau kaget, kebutuhan seks, obat-obatan, lakohol dan merokok cenderung meningkat.

\section{c. Faktor-faktor yang Mempengaruhi Stres}

Terdapat beberapa faktor yang dapat mempengaruhi stres. Faktor-faktor yang dapat mempengaruhi stres menurut Santrock (2003: 560-565) yaitu:

1) Faktor Lingkungan

a. Beban yang terlalu berat, konflik, dan frustasi istilah yang sering digunakan untuk beban yang terlalu berat di masa kini adalah burnout, perasaan tidak berdaya, tidak memiliki harapan, yang disebabkan oleh stres akibat pekerjaan yang sangat berat. Burnout membuat penderitanya merasa sangat kelelahan secara fisik dan emosional.

b. Kejadian besar dalam hidup dan gangguan sehari-hari. Para Psikolog menekankan bahwa kehidupan sehari-hari dapat menjadi penyebab stres seperti halnya kejadian besar dalam hidup. Tinggal dengan keluarga yang mengalami ketegangan dan hidup dalam kemiskinan bukanlah sesuatu yang dapat dianggap sebagai kejadian besar dalam hidup seorang remaja, namun kejadian sehari-hari yang dialami remaja dalam kondisi kehidupan seperti itu dapat menumpuk sehingga menimbulkan kehidupan yang sangat penuh dengan stres, dan pada akhirnya remaja akan mengalami gangguan psikologis atau penyakit.

2) Faktor-faktor kepribadian pola tingkah laku tipe A (type A behavior pattern) sekelompok karakteristik- rasa kompetitif yang berlebihan, kemauan keras, tidak sabar, mudah marah, dan sikap bermusuhan- yang dianggap berhubungan dengan masalah jantung. Individu yang bermusuhan dan parah sering diberi "reaktor panas", yang berarti mereka memiliki raksi fisiologis yang kuat terhadap stres-detak jantungnya meningkat, pernafasannya 
menjadi semakin cepat, dan otot-ototnya menegang, yang pada akhirnya dapat mengakibatkan penyakit jantung.

3) Faktor-faktor kognitif penilaian kognitif adalah istilah yang digunakan Lazarus untuk menggambarkan interpretasi individu terhadap kejadiankejadian dalam hidup mereka sebagai sesuatu yang berbahaya, mengancam, atau menantang dan keyakinan mereka apakah mereka memiliki kemampuan untuk menghadapi suatu kejadian dengan efektif.

4) Faktor-faktor Sosial-Budaya

a. Stres akulturatif (acculturation) mengacu pada perubahan kebudayaan yang merupakan akibat dari kontak langsung yang sifatnya terus menerus antara dua kelompok kebudayaan yang berbeda. Stres akulturatif (acculturative) adalah konsekuensi negatif dan akulturasi.

b. Status sosial-ekonomi kondisi kehidupan yang kronis, seperti pemukiman yang tidak memadai, lingkungan yang berbahaya, tanggung jawab yang berat, dan ketidakpastian keadaan ekonomi merupakan pemicu stres yang kuat dalam kehidupan warga yang miskin.

Adapun faktor-faktor yang mempengaruhi stres dalam menyusun skripsi pada mahasiswa menurut pendapat Gunawati \& Listiara (2006: 99-100), antara lain:

1) Faktor internal mahasiswa

a) Jenis kelamin. Penelitian di Amerika Serikat menyatakan bahwa wanita cenderung memiliki tingkat stres yang lebih tinggi dibandingkan pria. Secara umum wanita mengalami stres $30 \%$ lebih tinggi dari pada pria.

b) Status sosial ekonomi. Orang yang memiliki status sosial ekonomi yang rendah cenderung memiliki tingkat stres yang tinggi. Rendahnya pendapatan menyebabkan adanya kesulitan ekonomi sehingga sering menyebabkan tekanan dalam hidup. 
c) Karakteristik kepribadian mahasiswa. Adanya perbedaan karakteristik kepribadian mahasiswa yang sedang menyusun skripsi menyebabkan adanya perbedaan reaksi terhadap sumber stres yang sama. Mahasiswa yang memiliki kepribadian ketabahan memiliki daya tahan terhadap sumber stres yang lebih tinggi dari pada mahasiswa yang tidak memiliki kepribadian ketabahan.

d) Strategi koping mahasiswa. Strategi koping merupakan rangkaian respon yang melibatkan unsur-unsur pemikiran untuk mengatasi permasalahan sehari-hari dan sumber stres yang menyangkut tuntutan dan ancaman yang berasal dari lingkungan sekitar. Strategi koping yang digunakan oleh mahasiswa yang sedang menyusun skripsi dalam menghadapi stres, berpengaruh pada tingkat stresnya.

e) Suku dan kebudayaan

f) Inteligensi. Mahasiswa yang mempunyai tingkat inteligensi yang lebih tinggi akan lebih tahan terhadap sumber stres dari pada mahasiswa yang memiliki inteligensi rendah, karena tingkat inteligensi berkaitan dengan penyesuaian diri. Mahasiwa yang memiliki inteligensi yang tinggi cenderung lebih adaptif dalam menyesuaikan diri.

2) Faktor eksternal

a. Tuntutan pekerjaan/ tugas akademik (skripsi) yang dianggap berat dan tidak sesuai dengan kemampuan individu dapat menyebabkan terjadinya stres.

b. Hubungan mahasiswa dengan lingkungan sosialnya. Hubungan mahasiswa yang sedang menyusun skripsi dengan lingkungan sosialnya meliputi dukungan yang diterima dan integrasi dalam hubungan interpersonal dengan lingkungan sosialnya.

\section{Self Efficacy}

a. Pengertian Self Efficacy 
Menurut Bandura (1997: 42) Self efficacy adalah keyakinan yang dipegang seseorang tentang kemampuannya dan juga hasil yang akan diperoleh dari kerja kerasnya mempengaruhi cara mereka berperilaku. Self efficacy merupakan salah satu aspek pengetahuan tentang diri atau self knowledge yang paling berpengaruh dalam kehidupan manusia sehari-hari. Hal ini disebabkanself efficacy yang dimiliki ikut mempengaruhi individu dalam menentukan tindakan yang akan dilakukan untuk mencapai suatu tujuan termasuk didalamnya perkiraan berbagai kejadian yang akan dihadapi.

Menurut Alwisol (2009: 287) menyatakan bahwa "self efficacy adalah penilaian, apakah dapat melakukan tindakan yang baik dan buruk, tepat atau salah, bisa atau tidak mengerjakan sesuai dengan dipersyaratkan". Self efficacy yakni keyakinan bahwa seseorang bisa menguasai situasi dan mendapatkan hasil positif.

Berdasarkan pengertian diatas, dapat disimpulkan bahwa self efficacy merupakan keyakinan atau kepercayaan individu terhadap kemampuan yang dimilikinya dalam melaksanakan dan menyelesaikan tugas-tugas yang dihadapi, sehingga mampu mengatasi rintangan dan mencapai tujuan yang diharapkan.

\section{b. Aspek-aspek Self Efficacy}

Bandura (1997: 42) menyatakan bahwa efikasi diriyang dimiliki setiap individu berbeda didasarkan atas tiga dimensi yaitu level, strength, dan generality. Masing-masing dimensi mempunyai implikasi penting dalam performansi yang secara jelas dapat diuraikan sebagai berikut:

1) Level (tingkat)

Dimensi level mengacu pada persepsi tentang masalah yang berkaitan dengan derajat kesulitan tugas individu. Persepsi tentang derajat kesulitan tugas ini dipengaruhi oleh kompetensi yang dimiliki oleh individu tersebut. Dimensi level berimplikasi pada pemilihan perilaku yang akan dicoba oleh individu berdasar ekspektasi efikasi pada tingkat kesulitan tugas. Individu 
akan berupaya mengerjakan tugas tertentu yang dirasa mampu dilaksanakannya dan ia akan menghindari situasi atau perilaku yang dirasa berada di luar batas kemampuannya.

2) Strength (kekuatan)

Dimensi strength berkaitan dengan kekuatan pada keyakinan individu atas kemampuannya ketika menghadapi suatu tugas atau permasalahan. Individu yang memiliki keyakinan kuat akan tekun pada usahanya meskipun ada tantangan. Pengharapan yang kuat dan mantap pada individu akan mendorong untuk gigih dalam berupaya mencapai tujuan, walaupun mungkin belum memiliki pengalaman-pengalaman yang menunjang. Sebaliknya pengharapan yang lemah dan ragu-ragu akan kemampuan diri akan mudah digoyahkan oleh pengalaman-pengalaman yang tidak menunjang.

3) Generality (generalitas)

Dimensi generality berkaitan dengan taraf keyakinan dan kemampuan individu dalam menggeneralisasikan tugas dan pengalaman sebelumnya. Dimensi ini juga berkaitan dengan cakupan luas bidang tingkah laku dimana individu merasa yakin terhadap kemampuan dirinya. Individu dapat merasa yakin terhadap kemampuan dirinya tergantung pada pemahaman kemampuan dirinya yang terbatas pada suatu aktivitas dan situasi tertentu atau pada serangkaian aktivitas dan situasi yang lebih luas dan bervariasi.

\section{Social Support}

\section{a. Pengertian Social Support}

Sarafino (1994 : 102) yang menyatakan bahwa social support mengacu pada memberikan kenyamanan pada orang lain, merawatnya, atau menghargainya. Pendapat senada juga diungkapkan oleh Sarason (dalam Smet 1994:135) yang menyatakan bahwa social support adalah adanya interaksi interpersonal yang ditunjukkan dengan memberikan bantuan pada individu lain, dimana bantuan itu umumnya diperoleh dari orang yang berarti bagi individu yang bersangkutan. Social support dapat berupa pemberian informasi, bantuan 
tingkah laku, ataupun materi yang didapat dari hubungan sosial akrab yang dapat membuat individu merasa diperhatikan, bernilai dan dicintai.

Gottlieb (dalam Smet, 1994 : 135) menyatakan social support terdiri dari informasi atau nasehat verbal maupun non verbal, bantuan nyata, atau tindakan yang didapat karena kehadiran orang lain dan mempunyai manfaat emosional atau efek perilaku bagi pihak penerima. Pierce (dalam Kail \& Cavanaugh, 2000) mendefinisikan social support sebagai sumber emosional, informasional atau pendampingan yang diberikan oleh orang-orang disekitar individu untuk menghadapi setiap permasalahan dan krisis yang terjadi sehari-hari dalam kehidupan.

Berdasarkan uraian di atas dapat disimpulkan bahwa social support adalah dukungan atau bantuan yang berasal dari orang yang memiliki hubungan sosial akrab dengan individu yang menerima bantuan. Bentuk dukungan ini dapat berupa infomasi, tingkah laku tertentu, ataupun materi yang dapat menjadikan individu yang menerima bantuan merasa disayangi, diperhatikan dan bernilai.

\section{b. Bentuk-bentuk Social Support}

Sarafino (2011: 82) juga mengemukakan bahwa terdapat empat dukungan sosial, yaitu: (1) Dukungan emosional, (2) Dukungan nyata atau instrumental, (3) Dukungan informasi, (4) Dukungan persahabatan. Adapun rumusan penjelasan pernyataan diatas adalah sebagai berikut :

1) Dukungan emosional, bentuk dukungan ini berupa menyampaikan empati, rasa kepedulian, rasa perhatian, menyampaikan hal positif, dan dorongan kearah individu untuk menjadikan lebih percaya diri, hal ini memberikan kenyamanan dan diperhatikan dan rasa dicintainya individu pada saat stres.

2) Dukungan nyata atau instrumental, bentuk dukungan ini yaitu melibatkan bantuan langsung, seperti ketika orang memberikan atau meminjamkan uang atau membantu tugas-tugas pada saat stres. 
3) Dukungan informasi, bentuk dukungan ini yaitu memberikan saran, arah, atau umpan balik tentang bagaimana orang tersebut melakukan, misalnya orang sakit bisa mendapatkan informasi dari keluarga atau dokter tentang cara mengobati penyakit.

4) Dukungan persahabatan, dukungan ini mengacu pada ketersediaan orang lain untuk menghabiskan waktunya dengan individu, dengan seperti itu individu akan merasa bahwa orang lain juga merasakan dengan seperti apa yang ia rasakan.

\section{Metode Penelitian}

Dalam metode penelitian akan diuraikan mengenai: (1) jenis penelitian, (2) variabel penelitian, (3) populasi dan sampel, (4) metode dan alat pengumpulan data dan (5) Hasil uji validitas dan Reliabilitas, (6) hasil penelitian. Berikut uraiannya yaitu:

\section{c. Jenis Penelitian}

Dalam penelitian ini, peneliti menggunakan jenis penelitian kuantitatif kolerasional. Menurut Arikunto (2010) jenis penelitian kuantitatif kolerasional adalah penelitian yang digunakan untuk menganalisis ada tidaknya hubungan antara dua variabel atau lebih. Peneliti menggunakan jenis penelitian kuantitatif kolerasional karena peneliti memiliki tujuan untuk mengetahui hubungan antara self efficacy dan social support dengan tingkat stress pada mahasiswa akhir penyusun skripsi di FIP UNNES tahun 2019.

\section{d. Variabel Penelitian}

Menurut Sugiyono (2017) variabel adalah atribut atau sifat, obyek atau kegiatan dengan variasi tertentu yang ditetapkan peneliti sebagai bahan yang dipelajari secara fokus serta nanti akan ditarik kesimpulannya. Dalam penelitian ini menggunakan variabel self efficacy (X1) dan social support (X2) sebagai variableindependen atau variabel bebas dan variabel tingkat stres (Y) sebagai variable dependen atau variabel terikat.

\section{c. Populasi dan Sampel}


Populasi dalampenelitianini adalah mahasiswa yang sedang dalam menyelesaikan skripsi pada semester akhir yaitu semester 14 angkatan 2012 di FIP UNNES tahun 2019 yang berjumlah 77 orang. Sedangkan dalam menentukan ukuran sampel, peneliti mengacu pada pendapat Arikunto ( 2013:134) yang menyatakan apabila populasi kurang dari 100 maka diambil seluruhnya, namun apabila populasi lebih dari 100 orang maka sampel diambil 10-15\% atau 20-25\% atau lebih, tergantung dari kemampuan peneliti dilihat dari waktu, tenaga, dana dan sempit luasnya wilayah pengamatan dari setiap subjek karena hal ini menyangkut banyak sedikitnya data, besar kecilnya resiko yang ditanggung oleh peneliti.

Berdasarkan penelitian ini karena jumlah populasi hanya 77 mahasiswa, sesuai dengan pendapat Arikunto maka sampel yang diambil adalah keseluruhan dari jumlah populasi tersebut. Dengan demikian penggunaan seluruh populasi tanpa harus mengambil sampel penelitian disebut sebagai studi populasi.

\section{d. Metode dan Alat Pengumpul Data}

Metode pengumpul data merupakan salah satu tahap sistematis yang harus dilalui oleh peneliti dalam memperoleh informasi penting yang dibutuhkan sebagai bahan penelitian. Dalam penelitian ini, peneliti menggunakan metode pengumpul data yang mengukur aspek psikologi atau biasa disebut skala psikologis. Skala psikologis digunakan untuk mengungkap keadaan psikologis dari aspek kepribadian individu. Dalam penelitian ini skala psikologi digunakan untuk mengukur tingkat stres, self efficacy dan social support. Sehingga alat pengumpul data yang digunakan yaitu skala tingkat stres, skala self efficacy dan skala social support. Berikut akan diuraikan mengenai kisi-kisi intrumen setiap skala, yaitu:

Tabel 4.1

Kisi-kisi Skala Tingkat Stres

\begin{tabular}{ccccc} 
VARIABEL INDIKATOR & DESKRIPTOR & $\begin{array}{c}\text { NOMOR } \\
\text { ITEM }\end{array}$ & TOTAL \\
\hline
\end{tabular}




\begin{tabular}{|c|c|c|c|c|c|}
\hline & \multirow[b]{2}{*}{ Aspek Biologis } & & \multirow{2}{*}{$\begin{array}{c}\mathbf{( + )} \\
11,12 \\
15,31\end{array}$} & \multicolumn{2}{|l|}{$(-)$} \\
\hline \multirow[t]{8}{*}{$\begin{array}{l}\text { Tingkat } \\
\text { Stres }\end{array}$} & & $\begin{array}{l}\text { Mengalami gangguan } \\
\text { tidur, ganguan makan } \\
\text { dan sakit kepala, } \\
\text { produksi } \\
\text { yang keringat } \\
\text { pernafasan jerlebihan, } \\
\text { yang tidak teratur, } \\
\text { dalam melakukan } \\
\text { suatu hal cenderung } \\
\text { gugup, cemas, dan } \\
\text { gelisah }\end{array}$ & & $\begin{array}{l}1,3 \\
4,5 \\
6,7\end{array}$ & 10 \\
\hline & $\begin{array}{l}\text { Aspek } \\
\text { Psikologis }\end{array}$ & $\begin{array}{l}\text { Mengalami gangguan } \\
\text { daya ingat, perhatian, } \\
\text { dan susah untuk } \\
\text { berkonsentrasi. }\end{array}$ & 16,32 & $\begin{array}{l}10 \\
21\end{array}$ & 3 \\
\hline & & $\begin{array}{l}\text { Memiliki harga diri } \\
\text { yang rendah dan takut } \\
\text { gagal. }\end{array}$ & $\begin{array}{c}14,18 \\
25\end{array}$ & $\begin{array}{l}9 \\
23\end{array}$ & 5 \\
\hline & & $\begin{array}{l}\text { Memiliki kecemasan } \\
\text { akan masa depan, } \\
\text { emosi yang labil }\end{array}$ & 13 & $\begin{array}{c}2, \\
30\end{array}$ & 3 \\
\hline & & $\begin{array}{l}\text { Mempunyai } \\
\text { kecemasan yang } \\
\text { berlebihan terhadap } \\
\text { segala sesuatu dan } \\
\text { depresi. }\end{array}$ & 28 & $\begin{array}{l}24 \\
33 \\
34\end{array}$ & 4 \\
\hline & & $\begin{array}{l}\text { Tidak mampu } \\
\text { mengatasi masalah, } \\
\text { merasa ketakutan dan } \\
\text { merasa tertekan }\end{array}$ & 17 & $\begin{array}{l}26 \\
35\end{array}$ & 3 \\
\hline & & $\begin{array}{l}\text { Sulit bekerjasama } \\
\text { dengan orang lain, dan } \\
\text { kehilangan minat }\end{array}$ & 19,36 & $\begin{array}{l}8, \\
22\end{array}$ & 4 \\
\hline & & $\begin{array}{ll}\text { Susah untuk rileks } \\
\text { mudah terkejut, dan } \\
\text { kaget }\end{array}$ & 20 & $\begin{array}{l}27 \\
29\end{array}$ & 3 \\
\hline & & TOTAL & & & 36 \\
\hline
\end{tabular}

Tabel 4.2

Kisi-kisi Instrumen Skala Self Efficacy

\section{VARIABEL \\ INDIKATOR}

DESKRIPTOR

NOMOR
ITEM TOTAL




\begin{tabular}{|c|c|c|c|c|c|}
\hline & & & & & \\
\hline & & & + & - & \\
\hline Self Efficacy & Level & $\begin{array}{l}\text { Persepsi tentang } \\
\text { tingkat kesulitan } \\
\text { tugas }\end{array}$ & 1,2 & 3,4 & 4 \\
\hline & & $\begin{array}{l}\text { Sikap } \\
\text { dalammenghada } \\
\text { pi situasi sulit }\end{array}$ & 5,6 & $\begin{array}{c}7,8 \\
9\end{array}$ & 5 \\
\hline & Strengh & $\begin{array}{l}\text { Tingkat } \\
\text { keyakinan } \\
\text { terhadap } \\
\text { kompetensi diri } \\
\text { dalam } \\
\text { menghadapi } \\
\text { tugas }\end{array}$ & $\begin{array}{l}10 \\
11\end{array}$ & $\begin{array}{l}12 \\
13 \\
14\end{array}$ & 5 \\
\hline & & $\begin{array}{l}\text { Kegigihan dalam } \\
\text { menghadapi } \\
\text { rintangan }\end{array}$ & $\begin{array}{l}15 \\
16 \\
17\end{array}$ & $\begin{array}{l}18 \\
19\end{array}$ & 5 \\
\hline & & $\begin{array}{l}\text { Usaha } \\
\text { untukmencapai } \\
\text { tujuan yang } \\
\text { diharapkan }\end{array}$ & $\begin{array}{l}20 \\
21\end{array}$ & $\begin{array}{l}22, \\
23\end{array}$ & 4 \\
\hline & Generality & $\begin{array}{l}\text { Taraf keyakinan } \\
\text { dalam } \\
\text { menghadapi } \\
\text { tugas yang } \\
\text { bervariasi }\end{array}$ & $\begin{array}{l}24 \\
25\end{array}$ & $\begin{array}{l}26 \\
27\end{array}$ & 4 \\
\hline & & $\begin{array}{l}\text { Kemampuan } \\
\text { menghadapi } \\
\text { tugas yang } \\
\text { bervariasi }\end{array}$ & $\begin{array}{l}28 \\
29\end{array}$ & $\begin{array}{c}30 \\
31\end{array}$ & 4 \\
\hline & & TOTAL & & & 31 \\
\hline
\end{tabular}

Tabel 4.3

Kisi-kisi Skala Social Support

\begin{tabular}{|c|c|c|c|}
\hline VARIABEL & INDIKATOR & DESKRIPTOR & $\begin{array}{c}\text { NOMOR } \\
\text { ITEM }\end{array}$ \\
\hline
\end{tabular}

$(+) \quad(-)$ 


\begin{tabular}{|c|c|c|c|c|c|}
\hline $\begin{array}{l}\text { Social } \\
\text { Support }\end{array}$ & $\begin{array}{l}\text { Dukungan } \\
\text { Emosional }\end{array}$ & $\begin{array}{l}\text { Mendapatkan } \\
\text { perhatian yang } \\
\text { cukup dari orang lain } \\
\text { (keluarga, dosen, dan } \\
\text { teman ) }\end{array}$ & 1,4 & 2,3 & 4 \\
\hline & & $\begin{array}{l}\text { Memiliki kedekatan } \\
\text { yang erat dengan } \\
\text { oranglain (keluarga, } \\
\text { dosen, dan teman) }\end{array}$ & 5,7 & 6 & 3 \\
\hline & $\begin{array}{l}\text { Dukungan } \\
\text { Penghargaan }\end{array}$ & $\begin{array}{l}\text { Memperoleh } \\
\text { ungkapan positif dari } \\
\text { oranglain (keluarga, } \\
\text { dosen, dan teman). }\end{array}$ & $\begin{array}{l}8, \\
11 \\
15\end{array}$ & $\begin{array}{l}12 \\
13\end{array}$ & 5 \\
\hline & & $\begin{array}{l}\text { Memperoleh } \\
\text { motivasi dari } \\
\text { oranglain (keluarga, } \\
\text { dosen, dan teman). }\end{array}$ & 9 & $\begin{array}{l}10 \\
14\end{array}$ & 3 \\
\hline & $\begin{array}{l}\text { Dukungan } \\
\text { Instrumental }\end{array}$ & $\begin{array}{l}\text { Memperoleh } \\
\text { bantuan dari } \\
\text { oranglain (keluarga, } \\
\text { dosen, teman) }\end{array}$ & $\begin{array}{l}16, \\
18, \\
23 \\
24\end{array}$ & $\begin{array}{l}17 \\
20\end{array}$ & 6 \\
\hline & & $\begin{array}{l}\text { Memperoleh fasilitas } \\
\text { lengkap untuk } \\
\text { mendukung proses } \\
\text { menyusun skripsi }\end{array}$ & $\begin{array}{l}19, \\
25 \\
26\end{array}$ & $\begin{array}{l}21 \\
22\end{array}$ & 5 \\
\hline & $\begin{array}{l}\text { Dukungan } \\
\text { Informasi }\end{array}$ & $\begin{array}{l}\text { Mendapatkan } \\
\text { nasihat dari } \\
\text { oranglain (keluarga, } \\
\text { dosen dan teman) } \\
\text { terhadap kesulitan } \\
\text { yang dihadapi. }\end{array}$ & $\begin{array}{l}27 \\
28, \\
29 \\
30\end{array}$ & 31 & 5 \\
\hline & & $\begin{array}{l}\text { Mendapatkan } \\
\text { informasi yang } \\
\text { berkaitan dengan } \\
\text { penyelesaian } \\
\text { masalah dalam } \\
\text { proses menyusun } \\
\text { skripsi. }\end{array}$ & $\begin{array}{l}32 \\
35 \\
36\end{array}$ & $\begin{array}{l}33 \\
34\end{array}$ & 5 \\
\hline & & OTAL & & & 36 \\
\hline
\end{tabular}

\section{e. Uji Validitas dan Reliabilitas}


Instrumen diatas dijadikan sebagai pedoman saat melakukan uji coba penelitian dengan sampel 20 mahasiswa di Fakultas Ilmu PendidikanUniversitas Negeri Semarang. Dalam perhitungan menggunakan aplikasi Statistical Product and Services Solution 21 (SPSS). Untuk mengetahui valid tidaknya butir item instrumen dapat digunakan nilai signifikansinya. Data dapat dikatakan valid apabila memiliki taraf signifikansi diatas 5\%. Berdasarkan hasil perhitungan, ada beberapa aitem yang dinyatakan tidak valid sehingga aitem tersebut harus gugur.

Nomor item pada skala tingkat stres yang dinyatakan tidak valid yaitu 8, $11,13,14,17,19,21$ dan 36 . Untuk semua item skala self efficacy dinyatakan valid. Sedangkan untuk item skala social support yang dinyatakan tidak valid yaitu 5,13 , $16,24,25,28,29,32,35$ dan 36. Selain nomor tersebut dinyatakan valid dan digunakan pada penelitian sesungguhnya.

Penelitian yang baik harus memiliki instrumen penelitian yang valid dan reliabel. Uji Reliabilitas juga menggunakan bantuan program Statistical Product and Services Solution 21 (SPSS). Dimana suatu konstruk dikatakan reliabel ketika nilai rhitung $>0,70$. Berikut uaian hasil uji reliabel:

Tabel 4.4

Keputusan Hasil Uji Reliabilitas

\begin{tabular}{lccc}
\hline \multicolumn{1}{c}{ Instrumen } & r hitung & $\begin{array}{c}\mathbf{r} \text { tabel } \\
\text { padasignifikansi(5\%) } \\
\mathbf{N}=20\end{array}$ & Keterangan \\
\hline Tingkat Stres & 0,958 & 0,444 & Reliabel \\
Self Efficacy & 0,956 & 0,444 & Reliabel \\
Social Support & 0,919 & 0,444 & Reliabel \\
\hline
\end{tabular}

Dari tabel diatas dapat kita simpulkan bahwa variabel yang diteliti yaitu variabel tingkat stres, self efficacy dan social support telah dinyatakan reliabel karena sudah memenuhi syarat yaitu nilai rhitung setiap variabel lebih besar dari 0,7 . 


\section{f. Hasil Penelitian}

Untuk mengetahui adanya hubungan dan seberapa besar nilai hubungan antar variabel yang diteliti, menggunakan uji analisis regresi dengan menggunakan bantuan program Statistical Product and Services Solution 21 (SPSS). Berikut akan diuraian mengenai hasil uji analisis regresi dalam bentuk tabel:

Tabel 6.1

Hasil Uji Analisis Regresi dengan Tingkat Stres

\begin{tabular}{lccc}
\multicolumn{1}{c}{ Variabel } & R & R2 & F \\
\hline Self Efficacy & 0,605 & 0,366 & 10,757 \\
Social Support & 0,084 & 0,108 & 2,688 \\
Self Efficacy dan Social Support & 0,689 & 0,474 & 6,703 \\
\hline
\end{tabular}

Besarnya hubungan dapat dilihat pada tabel nilai $\mathrm{R}$, dimana terdapat korelasi yang signifikan antara self efficacy dengan tingkat stres yaitu sebesar 0,605. Artinya semakin tinggi self efficacy maka semakin rendah tingkat stres. Selain itu, dari hasil tabel menunjukan adanya korelasi yang signifikan antara social support dengan tingkat stres yaitu sebesar 0,084. Artinya semakin tinggi social support mahasiswa maka akan semakin tinggi tingkat stres mahasiswa. Sedangkan, hubungan antara self efficacy dan social support dengan tingkat stres juga menunjukan korelasi yang signifikan yaitu sebesar 0,689.

\section{Simpulan}

Dari hasil penelitian, dapat disimpulkan bahwa terdapat korelasi yang signifikan antara variabel X dengan variabel Y. Secara garis besar dapat dikatakan sumbangan kontribusi self efficacy dengan tingkat stres sebesar 36,6\% yang artinya self efficacymemiliki hubungan yang signifikan meski hubungan nya tergolong sedang artinya semakin tinggi self efficacy mahasiswa maka semakin rendah tingkat stres. Sedangkan, sumbangan kontribusi social support dengan 
tingkat stres sebesar 10,8\% yang artinya semakin tinggi social supportmahasiswa maka semakin tinggi tingkat stres. Sumbangan kontribusiself efficacydan social support dengan tingkat stres sebesar 47,4\%.Bagi penelitian lanjutan disarankan untuk dapat melakukan penelitian kualitatif atau mixed methods agar dapat memahami lebih mendalam tentang tingkat stres, melakukan penelitian dengan setting yang berbeda seperti SD, SMP, SMA/SMK, dan Perguruan Tinggi dengan membandingkan setiap jenjang dan melihat seberapa besar pengaruh indikatorindikator dengan tingkat stres dalam studi eksperimen.

\section{DAFTAR PUSTAKA}

Agung, A. G., \& Santi, B. M. (2013). Hubungan Kecerdasan Emosi dan Self Efficacy dengan Tingkat Stres Mahasiswa yang sedang Mengerjakan Skripsi. Jurnal Penelitian Psikologi, 17 (2), 1-6.

Alwisol. (2009). Psikologi Kepribadian. Malang: UMM Press.

Arikunto, Suharsimi. (2013). Prosedur Penelitian Suatu Pendekatan Praktik. Jakarta: Rineka Cipta.

Bandura, A. (1997). Self Efficacy: The Exercise of Control. New York: Freeman and Company.

Feist, J., \& Feist, J. (2010). Teori Kepribadian (Edisi 7). Diterjemahkan Sjahputri. Jakarta : Salemba Humanika.

Gunawati, R. H. S., \& Listiara. (2006). Hubungan antara Efektivitas Kominikasi Mahasiswa-Dosen Pembimbing Utama Skripsi dengan Stres dalam Menyusun Skripsi pada Mahasiswa Program Studi Psikologi Fakultas Kedokteran Universitas Diponegoro. Jurnal Psikologi Universitas Diponegoro. 3 (2), 93115.

Hasan, A. B. (2008). Pengantar Psikologi Kesehatan Islam. Jakarta: Raja Grafindo Persada.

Maramis, W.F. (2009). Catatan Ilmu Kedokteran Jiwa. Surabaya: Airlangga University Press.

Santrock, J. W. (2003). Adolescence (Perkembangan Remaja). Jakarta: Penerbit Erlangga.

Sarafino, E. P., \& T.W Smith. (1994). Health Psychology: Biopsychosocial and Interaction. UnitedStates of America: John Wiley \& Sons. 
(2011). Health Psychology: Biopsychosocial Interactions Seventh Edition. New York: John Wiley \& Sons. Interactions Ed. 7th. Canada: Jhon Wiley \& Sons. (2012). Health Psychology : Biopsychosocial Smet, B. (1994). Psikologi Kesehatan. (terjemahan). Jakarta: Gramedia Widia.

Shofiyanti, N. Z. (2014). Kemampuan Mengelola Stres Akademik pada Mahasiswa yang sedang Skripsi Angkatan 2009 Program Studi PGPAUD. Zuama. 17 (2).

Sugiyono. (2017). Metode Penelitian Pendidikan. Bandung: Alfabet.

Tamara, J., \& Chris, A. (2018). Hubungan Stres dengan Prestasi Akademik di SMA Diakonia Jakarta. Tarumanegara Medical Journal. 1 (1), 116-121.

Weidner, G., Kohlmann, C. W., Dotzauer, E., \& Burns, L. R. (1996). The effects of academic stress on health behaviors in young adults. Anxiety, stress, and coping, 9(2), 123-133.

Zakaria, D. (2017). Tingkat Stres Mahasiswa Ketika Menempuh Skripsi. Skripsi Tidak Diterbitkan. Malang: Fakultas Psikologi Universitas Muhammadiyah Malang. 